http://jmscr.igmpublication.org/home/ ISSN (e)-2347-176x ISSN (p) 2455-0450 crossref DOI: https://dx.doi.org/10.18535/jmscr/v8i4.82

\title{
Tumor and tumor like lesions detected in autopsy specimens- A six year study done in a tertiary care hospital
}

\author{
Authors \\ Dr Lekshmidevi.P', Dr Cicy.P.. ${ }^{2 *}$, Dr S.Sankar ${ }^{3}$ \\ *Corresponding Author \\ Dr Cicy .P. J \\ Associate Professor Pathology, Government Medical College Kottayam, Kerala, India
}

${ }^{1,2}$ Assistant Professor, Department of Pathology, Government Medical College, Kottayam, Kerala, India

${ }^{3}$ Professor and Head of Department of Pathology, Government Medical College, Kottayam, Kerala, India

\begin{abstract}
Aim: The objective of this study was to analyse the different tumours and tumour like lesions detected in post mortem specimens we received in our institute over a period six years.

Methods: Our research is a descriptive observational study of tumour and tumour like pathologies detected in the post mortem specimens received over a 6 year period from Jan 2011 to Dec 2016 in the Pathology department, of our institution.

Results: A total 104 autopsy cases received in our department during this study period, were found to have presence of tumor or tumor like lesions. Among the 104 cases, 72 were non neoplastic lesions accounting for $69.2 \%$ cases and the remaining $30.8 \%$ were neoplasms. The age range was from 1 month to 86 years with the maximum cases (23\%) in the seventh decade. Mimickers of neoplasms detected were Tuberculoma inflammatory pseudo polyp, extramedullary hematopoiesis and diverticulum of small intestine. Leiomyoma, fibroma, thymoma and mature cystic teratoma comprised the benign category. The malignant lesions included are, renal cell carcinoma, metastatic adenocarcinoma, malignant thymoma and sarcoma.

Conclusions: Non neoplastic lesions constituted the majority (69.2\%) in our study. In the neoplastic category, benign tumors constituted the majority, $18.3 \%$ of the total cases. The remaining $12.5 \%$ were malignant neoplasms, of which renal cell carcinomas was the single largest group accounting for $2.9 \%$ of the total cases. The results of our study were comparable with other similar studies.

Keywords: non-neoplastic lesions, benign, neoplasms, malignancy, Postmortem.
\end{abstract}

\section{Introduction}

Post mortem studies are of great value and they help in revealing many undiagnosed neoplastic and non neoplastic pathologies. A detailed general examination and diligent sampling of suspicious lesions is of utmost importance in detecting many pathological lesions.

Morphological findings which are unrelated to the cause of death may be noticed in routine examination of medicolegal autopsies. These findings can be of great academic value and help to study the infrequent lesions which go undetected in a person's life. ${ }^{1}$ The medicolegal autopsy serves as an opportunity for studying not only medically diagnosed and treated neoplasms, but also the natural evolution of untreated disease. ${ }^{2}$ Autopsy also aids in the diagnosis of undiagnosed or misdiagnosed malignant tumours irrespective of underlying cause of death, which may or may not be 
related to malignancy. ${ }^{3}$ Histopathological examination is also important for assessing statistics of mortality which are essential for public health and health service planning. ${ }^{4}$

\section{Methods}

The present study is a descriptive analysis of autopsy cases were tumor and tumor like lesions were detected over a period of six years from January 2011 to December 2016 in the department of pathology government medical college, Kottayam, a tertiary care centre in south India. All types of neoplasms and tumor like lesions identified in the autopsy material were included in our study. Some cases were diagnosed clinically but in certain cases neoplasms were detected only after autopsy. The Haematoxylin \& Eosin stained slides were analyzed and serial sections were taken in relevant cases. The relevant clinical details and imaging findings were retrieved from the data entered in the registers.

This study was approved by the Institutional Review Board of our college. Data analysis was done using SPSS 16 software and the frequency tables were calculated.

\section{Objectives}

1. To study the tumours and tumour like lesions in autopsy specimens received at Department of Pathology, Government medical college, Kottayam.

2. To describe the common tumors detected in postmortem cases at Government medical college, Kottayam.

Type of Study: Descriptive observational study.

Study Setting: Dept of Pathology, Govt. Medical College, Kottayam.

Sample Size: Sample size is calculated by the formula

$$
\begin{array}{ll} 
& \mathrm{N}=\frac{4 \mathrm{pq}}{\mathrm{d}^{2}} \\
\mathrm{~N}=\text { sample size } & \mathrm{p}=\text { prevalence / proportion in } \\
\text { previous study } & \mathrm{q}=100-\mathrm{p} \quad \mathrm{d}=\text { precision / }
\end{array}
$$

Study Tools

1. Specimen requisition form

2. Instruments to take bits of tissues to be studied.

3. Reagents for tissue processing.

4. Instruments for making paraffin blocks and cutting thin sections from it.

5. Eosin- Haematoxylin stain

6. Glass slides and cover slips for mounting.

7. Microscope

8. Detailed proforma in each case

\section{Study Procedure}

Clinical details of each case were obtained from the specimen requisition forms. Specimens were fixed in $10 \%$ formalin. After 24 hours of formalin fixation and processing, 4 micron thick sections were made from paraffin embedded blocks and stained with Eosin and Haematoxylin.

Data was entered in MS-EXCEL and analysed using SPSS software. Outcome variable is expressed in terms of frequency and percentage.

Inclusion criteria- All post mortem cases where tumors or tumor like masses are detected during autopsy in forensic department, Government medical college, Kottayam.

Exclusion criteria Markedly autolysed or decomposed cases where proper histopathological diagnosis is not possible.

\section{Results}

A total 104 autopsy cases received in our department during this study period, were found to have presence of tumor or tumor like lesions. Among the 104cases, 72 were non neoplastic lesions accounting for $69.2 \%$ cases and the remaining $30.8 \%$ were neoplasms.

The age range was from 1 month to 86 years with the maximum cases $(23 \%)$ in the seventh decade (Figure 1). The male : female ratio was 1.6:1 with $61 \%$ of cases in males and $39 \%$ in females. 


\section{JMSCR Vol||08||Issue ||04||Page 455-460||April}

Figure 1 showing decade wise distribution of cases

\section{Decade wise distribution}

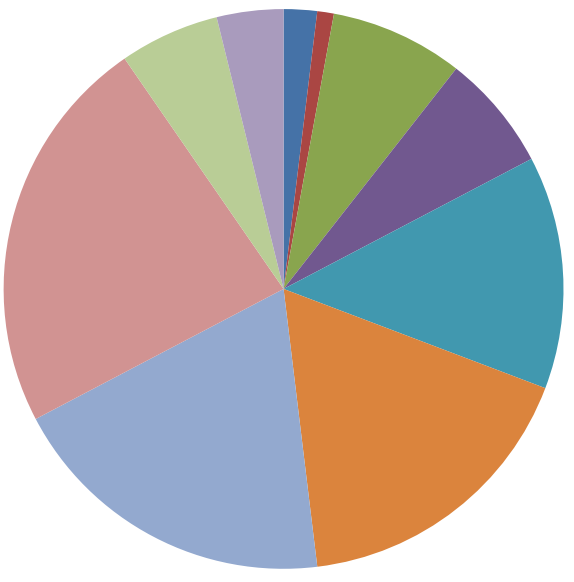

$-<1 \mathrm{yrs}$

$\square 1-9 \mathrm{yrs}$

10-20yrs

21-30yrs

31-40yrs

41-50yrs

51-60yrs

61-70yrs

71-80yrs

81-90yrs

Table 1 Relative frequency of pathologic lesions detected in autopsy specimens

\begin{tabular}{|l|c|c|}
\hline Type of lesion & Number of cases & $\%$ of cases \\
\hline $\begin{array}{l}\text { Reactive/Non } \\
\text { neoplastic }\end{array}$ & 72 & $69.2 \%$ \\
\hline Benign & 19 & $18.3 \%$ \\
\hline Malignant & 13 & $12.5 \%$ \\
\hline
\end{tabular}

The tumour like lesions accounted for the majority of lesions (69.2\%), followed by benign neoplasms (18.3\%). Malignancies constituted $12.5 \%$ of the total. (Table 1). The main systems with histopathological findings are shown in Figure 2.

Figure 2 Main systems with pathological findings in our study.

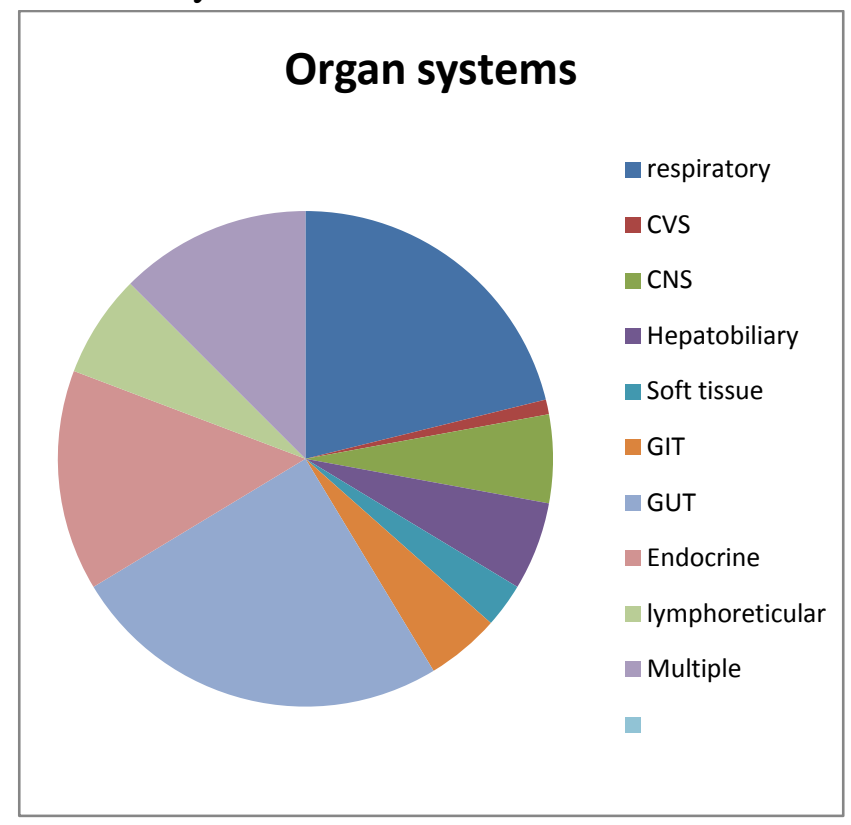

The non neoplastic lesions were chronic pancreatitis, granulomatous lesions like tuberculoma, inflammatory polyps etc. [Table 2] Benign cystic teratoma, leiomyoma, and fibroma comprised the benign category. The malignant ones were metastatic adenocarcinomas, renal cell carcinoma and sarcomas.

Table 2 shows the Reactive (Non neoplastic) lesions

\begin{tabular}{|c|c|c|c|}
\hline $\begin{array}{l}\text { Non neoplastic } \\
\text { lesions }\end{array}$ & Frequency & Site & Histopathology \\
\hline Worm mass & 1 & Appendix & $\begin{array}{l}\text { Helminthic } \\
\text { appendicitis }\end{array}$ \\
\hline Diverticulum & 2 & Small intestine & $\begin{array}{l}\text { Diverticulitis with } \\
\text { gangrene }\end{array}$ \\
\hline $\begin{array}{ll}\text { Nodular mass/ } \\
\text { Choristoma }\end{array}$ & 1 & Small intestine & Ectopic pancreas \\
\hline Mesenteric mass & 1 & Mesentry & $\begin{array}{l}\text { Necrotizing } \\
\text { granuloma }\end{array}$ \\
\hline $\begin{array}{l}\text { Multinodular } \\
\text { goiter }\end{array}$ & 4 & Thyroid & $\begin{array}{c}\text { Multinodular goiter } \\
\text { with degeneration }\end{array}$ \\
\hline Pneumonia & 12 & Lung & Pneumonia \\
\hline Tuberculoma & 3 & Lung & $\begin{array}{c}\text { Caseating } \\
\text { granuloma with } \\
\text { cavity }\end{array}$ \\
\hline $\begin{array}{l}\text { Granulomatous } \\
\text { lesion }\end{array}$ & 10 & $\begin{array}{c}\text { Lung, } \\
\text { liver,intestine }\end{array}$ & $\begin{array}{c}\text { Multiple } \\
\text { granulomas with } \\
\text { caseation ( } 7 \text { cases) } \\
\text { Non caseating( } 3 \\
\text { cases) }\end{array}$ \\
\hline Bronchiectasis & 1 & Lung & $\begin{array}{c}\text { Bronchiectatic } \\
\text { cavity with } \\
\text { caseating granuloma }\end{array}$ \\
\hline Simple cyst & 4 & $\begin{array}{c}\text { Liver } \\
\text { kidney }\end{array}$ & $\begin{array}{c}\text { Simple Hepatic cyst } \\
\text { Renal cortical cyst }\end{array}$ \\
\hline Hydatid cyst & 1 & $\begin{array}{l}\text { Interventicular } \\
\text { septum of heart }\end{array}$ & Hydatid cyst \\
\hline c/c pancreatitis & 11 & Pancreas & $\begin{array}{c}\text { Chronic pancreatitis } \\
\text { with calcification \& } \\
\text { dysplasia }\end{array}$ \\
\hline Abcess & 3 & $\begin{array}{c}\text { Retroperitoneu } \\
\mathrm{m}\end{array}$ & Suppurative lesion \\
\hline Polyp & 3 & $\begin{array}{l}\text { Colon ,ileum } \\
\text { Endometrial }\end{array}$ & $\begin{array}{l}\text { Inflammatory } \\
\text { pseudo polyp } \\
\text { endometrial polyp }\end{array}$ \\
\hline $\begin{array}{l}\text { Lymphoid } \\
\text { hyperplasia }\end{array}$ & 1 & Ileum & $\begin{array}{c}\text { Lymphoid } \\
\text { hyperplasia }\end{array}$ \\
\hline Hematoma & 2 & Subdural space & $\begin{array}{r}\text { Sub dural } \\
\text { hematoma }\end{array}$ \\
\hline Stricture & 2 & Colon,ileum & $\begin{array}{l}\text { sricture with } \\
\text { gangrene }\end{array}$ \\
\hline Multiple Nodules & 4 & Liver & $\begin{array}{c}\text { Cirrhosis with } \\
\text { dysplasia }\end{array}$ \\
\hline Xanthoma & 1 & Liver & Xanthoma \\
\hline $\begin{array}{l}\text { Xanthogranulomat } \\
\text { ous inflammation }\end{array}$ & 2 & $\begin{array}{l}\text { Kidney } \\
\text { Ovary }\end{array}$ & $\begin{array}{c}\text { Xathogranulomatou } \\
\text { s pyelonephritis } \\
\text { xanthogranulomato } \\
\text { us oophoritis }\end{array}$ \\
\hline Splenomegaly & 2 & Spleen & $\begin{array}{c}\text { Extramedullary } \\
\text { hematopoiesis }\end{array}$ \\
\hline Colloid cyst & 1 & Brain & $\begin{array}{c}\text { Colloid cyst of third } \\
\text { ventricle }\end{array}$ \\
\hline
\end{tabular}

\section{Benign neoplasms}

Benign neoplasms detected in the different organs are given in Table 3.The gross specimens of all were well circumscribed masses. 
Table 3 Benign neoplasms detected in autopsy specimens

\begin{tabular}{|c|c|c|c|}
\hline Benign & Frequency & Site & Histopathology \\
\hline Leiomyoma & 9 & $\begin{array}{l}\text { Uterus, } \\
\text { esophagus }\end{array}$ & Leiomyoma \\
\hline $\begin{array}{l}\text { Mature cystic } \\
\text { teratoma }\end{array}$ & 2 & $\begin{array}{c}\text { Ovary ,Sacrco } \\
\text { ccyx }\end{array}$ & $\begin{array}{c}\text { Benign cystic } \\
\text { teratoma }\end{array}$ \\
\hline $\begin{array}{l}\text { Sexcordstroma } \\
1 \\
\text { tumor/Fibroma }\end{array}$ & 1 & Ovary & Fibroma \\
\hline $\begin{array}{l}\text { Epithelial } \\
\text { tumor }\end{array}$ & 1 & Ovary & $\begin{array}{c}\text { Serous } \\
\text { cystadenoma }\end{array}$ \\
\hline Thymoma & 1 & Thymus & Type A thymoma \\
\hline Meningioma & 2 & Meninges & $\begin{array}{c}\text { Fibroblastic } \\
\text { meningioma, } \\
\text { Meningiothelial }\end{array}$ \\
\hline Pituitary tumor & 1 & Pituitary & Adenoma \\
\hline $\begin{array}{l}\text { Adrenal } \\
\text { tumor }\end{array}$ & 1 & Adrenal & Myelolipoma \\
\hline $\begin{array}{l}\text { Adrenal } \\
\text { tumor }\end{array}$ & 1 & Adrenal & Ganglioneuroma \\
\hline
\end{tabular}

\section{Malignant neoplasms}

In the category of malignant lesions renal cell carcinoma constituted the largest category (2.9\%), followed by, adenocarcinomas (1.9.\%) and other malignant neoplasms. The malignant tumors detected are shown Table 4.

Table 4 shows the malignant tumors detected

\begin{tabular}{|c|c|c|c|}
\hline Malignancy & $\begin{array}{c}\text { Freque } \\
\text { ncy }\end{array}$ & Site & Histopathology \\
\hline $\begin{array}{l}\text { Metastatic } \\
\text { Adenocarcinoma }\end{array}$ & 1 & Aorta & $\begin{array}{c}\text { Adenocarcinoma } \\
\text { mets }\end{array}$ \\
\hline Adenocarcinoma & 2 & $\begin{array}{c}\text { Colon } \\
\text { Retroperito } \\
\text { neum } \\
\end{array}$ & $\begin{array}{c}\text { Adenocarcinoma } \\
\text { Adenocarcinoma } \\
\text { mets }\end{array}$ \\
\hline $\begin{array}{ll}\text { Renal } & \text { cell } \\
\text { carcinoma }\end{array}$ & 3 & Kidney & $\begin{array}{c}\text { Multilocular cystic } \\
\text { RCC } \\
\text { Clear cell RCC } \\
\end{array}$ \\
\hline Sarcoma & 1 & Pancreas & Primary sarcoma \\
\hline $\begin{array}{l}\text { Carcinoma } \\
\text { pancreas }\end{array}$ & 1 & Pancreas & $\begin{array}{c}\text { Ductal } \\
\text { adenocarcinoma. }\end{array}$ \\
\hline Germ cell tumor & 1 & $\begin{array}{c}\text { Mediastinu } \\
\mathrm{m}\end{array}$ & Germ cell tumor \\
\hline Rhabdoid tumor & 1 & Extrarenal & Rhabdoid \\
\hline $\begin{array}{l}\text { Embryonal } \\
\text { sarcoma }\end{array}$ & 1 & Liver & Embryonal sarcoma \\
\hline $\begin{array}{ll}\begin{array}{l}\text { Plasma } \\
\text { dyscrasia }\end{array} & \text { cell } \\
\end{array}$ & 1 & Spleen & $\begin{array}{c}\text { Plasma cell } \\
\text { neoplasm }\end{array}$ \\
\hline Thymic carcinoma & 1 & Thymus & $\begin{array}{c}\text { TypeC Thymoma } \\
\text { with invasion }\end{array}$ \\
\hline
\end{tabular}

\section{Discussion}

Performance of a thorough autopsy on apparent natural deaths can provide invaluable information by identifying public health risks and monitoring disease trends. Histopathologic study in autopsies is of great value in detection of unsuspected neoplasms and evaluating the cause of death, also aiding to the true cancer incidence statistics. ${ }^{1}$ Many incidental findings detected on histopathological examinations have proven to be great learning tools for the pathologists as well as the forensic expert.

Of the total 104 cases in our study the majority was in seventh decade, with age range between 1 month to 98 yrs. Male:female ratio was 1.6:1. The majority of lesions were in genitourinary system 25\%(26 cases),followed by cardiovascular system $21 \%$ (22 cases) and endocrine system 14\%(15 cases).In 13\% of cases pathologic lesions were detected in multiple systems. Figure 2

The non neoplastic lesions which masequraded as tumors included granulomatous lesions, pancreatitis, Abscess, gangrene intestine, cysts and inflammatory polyps. Details are given in Table 2. We had 12 cases of tuberculosis .5 were incidentally detected but and in 4 cases the patient was already diagnosed but clinically it mimicked a mass lesion .2 cases of tuberculosis were detected as incidental findings in Patel et al s study. ${ }^{1}$ There were 11 cases of pancreatitis of which in 1 case there was coexisting adenocarcinoma.

Another important aspect is that discordance between clinical and postmortem findings can be detected and the underlying factors leading to such discrepancies can be analysed. According to Stevanovic $\mathrm{G}$ the overall rate of major discrepancies was 29 per cent. ${ }^{5}$ Malignancies were incorrectly diagnosed in $25.8 \%$ of cases. ${ }^{6}$ Hence autopsy studies are of significance in discovering many hidden pathologies.

In Patel et al s study malignant lesions accounted for $2.47 \%$ of cases. ${ }^{1}$ Renal cell carcinoma, Oncocytoma, carcinoid liver and an unusual pattern of tumor to tumor metastasis were some of the cases detected. ${ }^{1}$ In the present study, $30.8 \%$ cases were neoplastic lesions and $12.5 \%(n=13)$ of the total cases were malignancies. Adenocarcinoma and renal cell carcinoma were the malignancies detected in our study. Renal cell carcinomas have been incidently detected in many autopsy studies. ${ }^{1,7}$ Renal cell carcinomas diagnosed in post mortem 
cases were found to be at a lower stage and grade compared to those diagnosed antemortem. ${ }^{7}$

The $16 \%$ rate of undetected neoplasia for medical autopsies and the $44 \%$ discordant clinical versus autopsy diagnosis compare favorably with other studies and emphasize the need for autopsy evaluation of the nonforensic donor. ${ }^{3,8-12}$ Patient and family consent issues are also critical in autopsies. ${ }^{14}$

\section{Limitations Expected}

All autopsy cases with neoplasms may not be available for study especially if there is marked autolysis and in case of severe burns.

\section{Conclusion}

Results of the present study are comparable with other similar studies. (Table 5). Such studies may help to find out some of the undetected neoplasms and some unusual manifestations of certain pathologic lesions which will be of academic value .It might also serve as a useful study material for assessing statistics of certain malignancies.

Table 5 Comparison with other studies

\begin{tabular}{|l|c|c|c|}
\hline & Year & Total cases & $\begin{array}{c}\text { \% of } \\
\text { Malignancy }\end{array}$ \\
\hline Patel et al $^{1}$ & 2016 & 202 cases & $2.47 \%$ \\
\hline Burton et al $^{3}$ & 1998 & $\begin{array}{c}1105 \text { cases } \\
\text { M:F=1.5:1 }\end{array}$ & $22 \%(250$ cases $)$ \\
\hline Wells et al $^{14}$ & 1923 & - & $15 \%$ \\
\hline Bauer et al $^{12}$ & 1972 & - & $25 \%$ \\
\hline $\begin{array}{l}\text { Present } \\
\text { study }\end{array}$ & 2020 & $\begin{array}{c}104 \text { caes.M;F- } \\
1.6: 1\end{array}$ & $13 \%$ \\
\hline
\end{tabular}

\section{References}

1. Patel S, Rajalakshmi BR, Manjunath GV. Histopathologic Findings in Autopsies with Emphasis on Interesting and Incidental Findings-A Pathologist's Perspective. J Clin Diagn Res. 2016 Nov;10(11):EC08-EC12. doi: 10.7860/JCDR/2016/21106.8850. Epub 2016 Nov 1. PMID: 28050373; PMCID: PMC5198326.

2. Gezelius C, Eriksson A. neoplastic disease in a medicolegal autopsy material. A retrospective study in northern Sweden. Z Rechtsmed. 1988;101(2):115-30. [PubMed] [Google Scholar]
3. Burton EC, Troxclair DA, Newman WP. Autopsy diagnoses of malignant neoplasms: How often are clinical diagnose incorrect? JAMA. 1998;280(14):1245-48. [PubMed] [Google Scholar]

4. Jhajj KK, Nibhoria S, Sandhu SK, Bamra NS, Padda P. A study of histopathological examination in medico-legal autopsies in Faridkot, Punjab. IJFMT. 2013;7(1):254-87. [Google Scholar]

5. Stevanovic G, Tucakovic G, Dotlic R, Kanjuh V. Correlation of clinical diagnoses with autopsy findings: a retrospective study of 2,145 consecutive autopsies. Human pathology. 1986 Dec 1;17(12):1225-30.

6. Sarode VR, Datta BN, Banerjee AK, Banerjee CK, Joshi K, Bhusnurmath B, Radotra BD. Autopsy findings and clinical diagnoses: a review of 1,000 cases. Human Pathology. 1993 Feb 1;24(2):194-8.

7. Jonsson A, Hardarson S, Petursdottir V, Palsdottir HB, Jonsson E, Einarsson [7] GV, et al. Renal cell carcinoma diagnosed at autopsy in Iceland 1971-2005. Laeknabladid. 2008;94(12):807-12.

8. Avgerinos DV, Bjo“rnsson J. Malignant neoplasms: discordance between clinical diagnoses and autopsy findings in 3,118 cases. APMIS. 2001;109(11): 774-780.

9. Stenba“ck F, Pa“iva“rinta H. Relation between clinical and autopsy diagnoses, especially as regards cancer. Scand J Soc Med. 1980;8(2):67-72.

10. Szende B, Kendrey G, Lapis K, Lee PN, Roe FJ. Accuracy of admission and pre-autopsy clinical diagnoses in the light of autopsy findings: a study conducted in Budapest. Hum Exp Toxicol. 1994;13(10): 671-680.

11. De Pangher Manzini V, Revignas MG, Brollo A. Diagnosis of malignant tumor: comparison between clinical and autopsy diagnoses. Hum Pathol. 1995; 26(3):280283.

12. Bauer FW, Robbins SL. An autopsy study of cancer patients, I: accuracy of the clinical 
diagnoses (1955 to 1965) Boston City

Hospital. JAMA. 1972; 221(13):1471-1474.

13. Sens MA, Zhou XD, Weiland T, Cooley AM. Unexpected neoplasia in autopsies: potential implications for tissue and organ safety. Archives of pathology \& laboratory medicine. 2009 Dec;133(12):1923-31.

14. Wells HG. Relation of clinical to necropsy diagnosis in cancer and value of existing cancer statistics. JAMA.1923;80:737-740.

Google Scholar. 